\title{
Histomorphological Studies of the Perinatal Pig: Comparison of Five Mortality Groups with Unaffected Pigs
}

\author{
By $N$-E. Björklund, J. Svendsen and L. S. Svendsen
}

\begin{abstract}
Björklund, N-E., J. Svendsen and L. S. Svendsen: Histomorphological studies of the perinatal pig: Comparison of five mortality groups with unaffected pig. Acta vet. scand. 1987, 28, 105-116. - The results of a histological examination of organs obtained from 5 clinically and morphologically identified and described mortality groups of pigs dying during the perinatal period $(0-60 \mathrm{~h}$ of age) were compared with the results obtained from the same examination of unaffected, apparently normal pigs (0.4-60 h of age). The histomorphological pictures were judged blind according to a scale of 1 to 4 , where $1=$ none or insignificant, and $4=$ a high degree of a specific organ characteristic. The results for each organ characteristic were analysed statistically.
\end{abstract}

perinatal mortality; organs; histomorphological characteristics; stillborn; intra partum; weak; splayleg; trauma.

\section{Introduction \\ Losses during the perinatal period are re- sponsible for a great proportion of the total preweaning mortality in most sow herds. These losses may vary considerably from herd to herd, and usually have noninfectious causes (Nielsen et al. 1976, Svendsen et al. 1986).}

Among these losses, several perinatal "mortality groups" may clinically and morphologically be identified: stillborn intra partum pigs, weak and/or undersized pigs, splayleg pigs, splayleg and weak (splayweak) pigs, and traumatized pigs. The mortality groups do not always represent specific disease entities in the classical sense and the underlying cause(s) may vary within the group (Bille et al. 1974, Randall 1978, Svendsen 1982, Svendsen et al. 1986).

In a previous paper (Björklund et al. 1986), the frequency of some histomorphologically detectable organ characteristics from newborn, $0.4-60 \mathrm{~h}$ old unaffected pigs were presented together with a brief description of the litter factors influencing these observations. In the present paper, the frequency of the same organ characteristics in pigs of the same age that are classified as belonging to one of the mortality groups are compared to those of the unaffected pigs. This study was part of a larger project investigating the problems of perinatal mortality in pigs from the behavioural, managemental, pathological, biochemical, and physiological aspects and the methods of reducing these losses. 


\section{Materials and methods}

All animal material was collected over the period 1978-1983, and was obtained from a herd of 90 pure breed Swedish Landrace sows. Housing, feeding, management and handling of animals in this herd has been described previously (Jeppsson et al. 1980, Bengtsson et al. 1983).

The occurrence and characteristics of the perinatal mortality losses (presented as groups) in the herd over the period 1977-1981, and the herd and litter factors influencing these losses, are shown in Table 1. A total of 183 pigs, $0-60 \mathrm{~h}$ of age (Svendsen 1982, Björklund et al. 1987) were collected at random for organ weight and histomorphological studies (Table 2). The pigs were obtained from sows that had a normal pregnancy and farrowing, during the course of other studies covering farrowing and the perinatal period (0-3 days after birth). Approximately $50 \%$ of the pigs in the mortality groups, and all the unaffected pigs were sacrificed by bleeding from the axillary vein. All pigs were placed at $+4^{\circ} \mathrm{C}$ immediately after death, and post mortem examinations and organ weight determinations were carried out within $6 \mathrm{~h}$ of death. For euthanized pigs, these procedures were carried out immediately. The definition, description and specific post mortem observations for each mortality group (where applicable) are given below.

Unaffected group: contained apparently normal, vigourous pigs (Randall 1971, De Roth \& Downie 1976) which attempted to stand within $20 \mathrm{~s}$, and had teat contact within $10 \mathrm{~min}$ of birth. They were sacrificed at various times from $0.4-60 \mathrm{~h}$ after birth. Of the 28 pigs in this group, 23 had suckled (Björklund et al. 1987).

Stillborn intra partum (i.p.) group: contained those pigs which died during the birth process or immediately after. Many of the pigs had a detectable navel cord pulse at birth but they neither breathed successfully nor attempted to stand.

At post mortem, it was observed that many stillborn i.p. were still partly wrapped in the fetal membranes and several pigs were born with ruptured umbilical cords. A few of the cords were oedematous or contained haematomas. The organs appeared fresh and sometimes large amounts of a yellowish, serous liquid were seen in the thoracic and abdominal cavities. The lungs were usually atelectatic, or displayed partial atelectasis. Amniotic fluid mixed with meconium was always observed in the stomach, and often meconium was found in the larynx and trachea.

Weak group: contained pigs which at birth were judged to be unable to survive under standard husbandry conditions because they were too weak and/or too small. Guidelines for the diagnosis comprised one or more of the following: a birth weight below $900 \mathrm{~g}$ (mean herd birth weight is $1,500 \mathrm{~g}$ ); a time lapse of more than $20 \mathrm{~m}$ between birth and the first teat contact; an apparent inability to obtain or maintain a suckle, even when helped. Undersized but otherwise apparently normal pigs, and pigs which displayed signs of splayleg or other locomotor disorders after birth were not included in this group. The weak born pigs often had difficulty in orientation and sensing their environment with respect to such items as the location and movements of the sow, and the position of the heat lamp in the creep area. Difficulties with locomotion appeared as they became progressively weaker.

The post mortem findings in the weak pigs were in general non-specific, and to some extent resembled the findings for the stillborn i.p. group. A few of these pigs were still partly wrapped in their fetal membranes, and occasionally a short, oedematous umbi- 
Table 1. Characteristics of the perinatal mortality groups in the herd, and herd and litter factors influencing these losses. 702 litters.

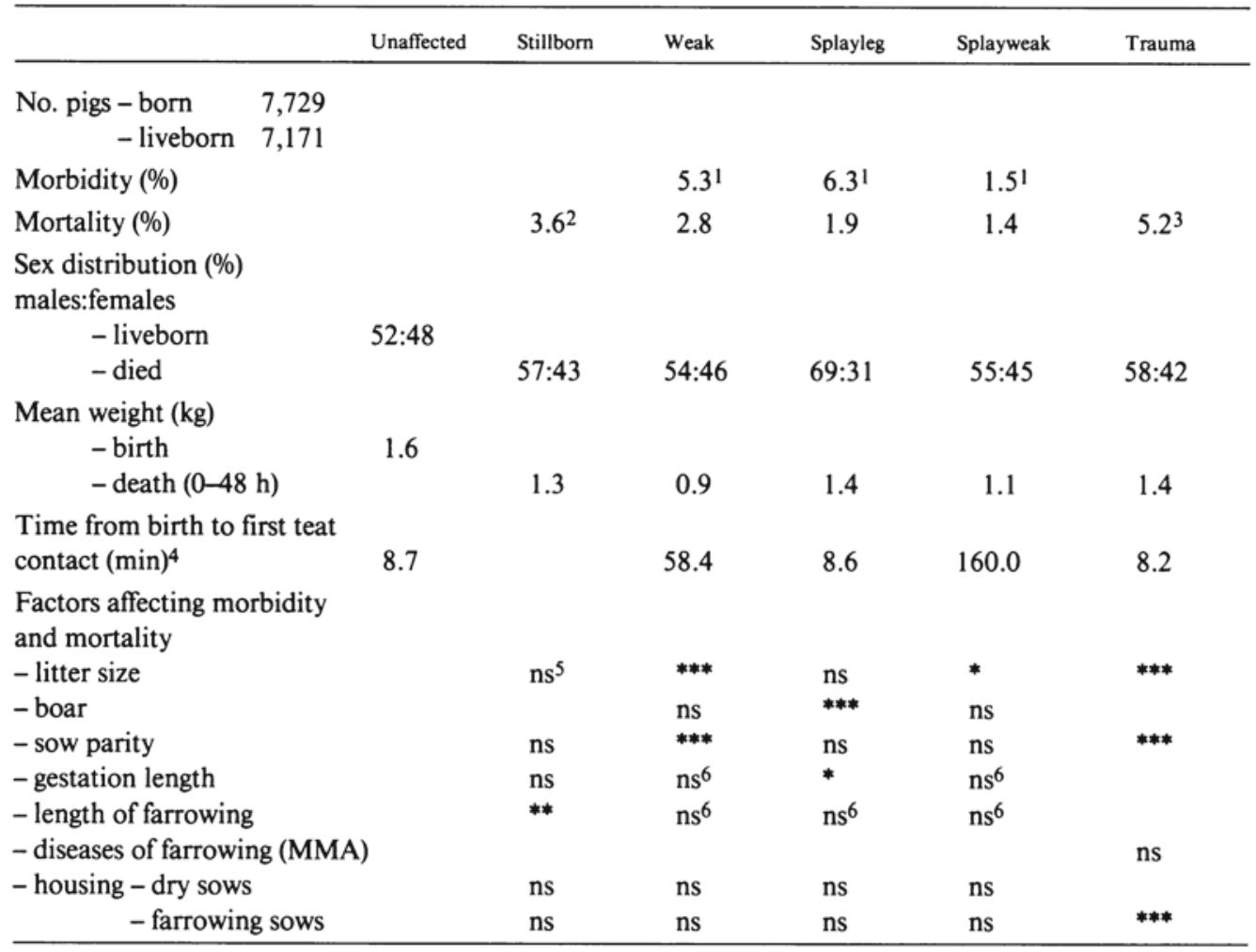

1 See Svendsen \& Bengtsson (1982b).

2 See Svendsen \& Bengtsson (1984).

${ }^{3}$ See Svendsen \& Bengtsson (1982a)

${ }^{4}$ Data obtained from behaviour studies for 40 litters, for all groups.

$5{ }^{* * *}=\mathrm{P}<0.001,{ }^{* *}=\mathrm{P}<0.01,{ }^{*}=\mathrm{P}<0.05, \mathrm{~ns}=$ not significant.

6 Was not included in the final statistical model.

Table taken from Svendsen et al. (1986).

lical cord was observed. Although most of the pigs had starved, they all displayed a moist musculature. Areas of atelectasis in the lungs were seen in some cases, and congested lungs and kidneys were common observations. Oedematous lungs were occasionally noted.

Splayleg group: contained pigs which showed signs of splayleg (congenital myofibrillar hypoplasia) (Thurley et al. 1967), about 3-8 h after birth. The syndrome appeared most severe within 24-36 h after birth. Usually, only the hindlegs were affected; when the piglet attempted to stand, the hindlegs extended sideways. Typically, the hindlegs were bilaterally and equally extended but, in some cases, both hindlegs extended to one side, or one leg extended backwards. Less severely affected pigs were able to stand unsteadily with the hindlegs 
Table 2. Characteristics of the perinatal mortality groups which were included in this investigation.

\begin{tabular}{llllllc}
\hline & Unaffected & Stillborn & Weak & Splayleg & Splayweak & Trauma \\
\hline No. pigs & 28 & 25 & 51 & 20 & 44 & 15 \\
No. litters & 22 & 14 & 40 & 19 & 30 & 14 \\
Mean age, hours & $20.3 \pm 21.9$ & 0 & $18.4 \pm 18.4$ & $24.8 \pm 28.6$ & $34.4 \pm 21.5$ & $7.6 \pm 8.7$ \\
$\begin{array}{l}\text { Mean gestation length, } \\
\text { days, }\end{array}$ & $115.0 \pm 1.6$ & $114.3 \pm 3.1$ & $114.3 \pm 2.2$ & $114.1 \pm 1.9$ & $114.8 \pm 2.2$ & $115.3 \pm 1.6$ \\
$\begin{array}{l}\text { Litter size, mean } \pm \text { s.d. } \\
\text { - No. born }\end{array}$ & $10.1 \pm 4.5$ & $11.9 \pm 3.5$ & $13.2 \pm 2.6$ & $12.3 \pm 3.1$ & $14.0 \pm 3.1$ & $11.7 \pm 3.4$ \\
- No. liveborn & $9.6 \pm 4.1$ & $9.7 \pm 4.1$ & $11.8 \pm 3.1$ & $11.6 \pm 3.1$ & $12.9 \pm 3.1$ & $11.2 \pm 3.8$ \\
$\begin{array}{l}\text { \% not starved } \\
\text { Sex distribution (\%) }\end{array}$ & 76 & & 26 & 53 & 14 & 75 \\
males:females & $68: 32$ & $68: 32$ & $52: 48$ & $70: 30$ & $61: 39$ & $73: 27$ \\
\hline
\end{tabular}

straddled. Often the splayleg pig attempted to place as much of its weight as possible on the forelegs when standing. Although these pigs had difficulty moving, they were judged to be vital and they were still strong enough to compete for a teat and obtain a suckle. Under normal husbandry conditions, and with taping of the hindlegs together to provide support, most splayleg pigs would eventually recover if they could avoid being traumatized by the sow.

At post mortem, the splayleg pigs appeared normal, except for displaying a typical pattern of usually bilateral abrasions and injuries on the accessory digits, the hocks, the pelvis and the tail. Subcutaneous oedema was generally observed along the hind leg.

Splayweak group: contained splayleg pigs that also displayed signs of weakness as described above; they did not have to be underweight, but did have a "confused" apathetic behaviour. These animals were generally unable to obtain or maintain a suckle even when helped, and rapidly became weaker than would be expected due to starvation alone.

Usually, these animals had both the forelegs and hindlegs extended to the sides, and the legs were bilaterally and equally affected.
The condition of the pig rapidly deteriorated. The recumbent pig frequently lay with the hindlegs extended along the body, and the forelegs spread sideways. The signs of weakness in these pigs were somewhat similar to those displayed by the "older" group of weak pigs, and unless the pigs were kept under constant observation after birth it could be very difficult to distinguish between the two groups. Most of these pigs, if not traumatized by the sow, died within $30-40 \mathrm{~h}$ after birth, even if they had been fed perorally. At post mortem, moist musculature was also a standard observation in the pigs of the splayweak group, where a typical pattern of injuries and abrasions could be seen on the accessory digits, the hocks, the sternum, the axillar and the mandible. In addition, these pigs often displayed more prominent symptoms of starvation than would be expected in "normal" starved pigs of the same age.

Trauma group: contained pigs which were overlain or crushed by the sow within the first $60 \mathrm{~h}$ after birth. Trauma was the primary cause of death, and was not secondary to an obviously predisposing factor such as weakness, splayleg, or infectious diseases. 
At post mortem, the stomach of the trauma pigs was often filled with unclotted colostrum. Otherwise, the post mortem findings depended upon the type of injuries present. In some established causes of traumatization by the sow, no lesions could be seen at post mortem. However, several of the pigs that died due to traumatic injuries showed exsanguination to the serous cavities. Liver rupture frequently occurred, whereas rupture of the spleen was rarely seen. Multiple rib fractures combined with perforation of the lungs and haemothorax were observed in a few cases.

Many pigs appeared to die because of choking, appearing slightly cyanotic, with the head and neck areas or the hindquarters congested and oedematous, and intramuscular haemorrhages frequently present. The lungs were usually oedematous, and petechial haemorrhages in the upper part of the respiratory tract were sometimes observed. Occasionally, fibrin threads were noted in the abdomen, and in a few cases small petechial bleedings in the kidneys were also found. In order to be included in the material for this study, the nature of the injuries sustained had to be such that none of the organs had obviously been affected by traumatization.

\section{Histomorphological examination \\ and statistical analysis}

The brain, lungs, heart, kidneys, pancreas, spleen, thymus, thyroid, and adrenals were weighed (Svendsen 1982), fixed in neutral formalin or in absolute alcohol, and studied for histology as previously described (Björklund et al. 1987). The main staining methods for paraffin embedded sections were haematoxylineosin (HE), van Gieson, and PAS before and after diastase treatment, and for frozen sections were scarlet red and Oilred- 0 .
The histological changes were judged according to a scale of $1-4$, where $1=$ none or insignificant, and $4=a$ high degree of the specific organ characteristic (Björklund et al. 1987). These organ characteristic were analysed and compared using statistical programs from the BMDP-Biomedical Computer Programs (Dixon \& Brown 1983), according to the models previosly described (Svendsen 1982, Björklund et al. 1987).

\section{Results and discussion}

The organ characteristics and their description for the unaffected group of pigs have been presented previously (Björklund et al. 1987). Upon comparison of these results with those for the mortality groups, it was noted that certain characteristics were common to all groups, and occurred at nearly the same frequency. These included:

- the amount of haematopoietic nodules in liver, spleen (with the exception of the splayweak group), and thymus;

- the amount of large vacuolated epithelial cells in the liver, bronchioli, and kidney tubules;

- the presence of oedema in the medulla of the kidney;

- the number of Hassall's corpuscles in the thymus;

- the presence of an immature outer nephrogenic zone of varying width in the kidneys;

- the presence of few layers of cells around the arteries in the white pulp of the spleen;

- the same variation in the appearance of the gland formation in the exocrine pancreas;

- no differences in the heart characteristics between the different mortality groups were noted.

Those organ characteristics which differed between the unaffected and the mortality 
groups are presented in Table 3.. The brain is under special study and the observations will be presented at a later date. The results and discussion for each mortality group are presented in the following:

\section{Stillborn i.p. group}

This group is the best defined mortality group and, at the same time, the one most different from the unaffected group. Many differences in the organ characteristics of this group were more apparent (Table 3). For example, the irregularities in the histological picture of the liver lobules (Fig. 1), developmental disturbances in the kidneys (Figs. 3-5), the increase in colloid free follicles in the thyroid (Fig. 2), and the various circulatory disturbances in the different organs, such as hyperemia.

According to many previous investigations, i.e. (Randall \& Penny 1967, 1968), hypoxia during the birth process appears to be associated with intrapartum losses. The increase in circulatory disturbances appearing as: hyperaemia and oedema in the lungs, hyperaemia in the liver and kidneys, and petechial bleedings in the kidney cortex (Table 3), may have been due to the stress of hypoxia superimposed upon the stress of birth. These types of changes have previously been described by Glastonbury (1977). High serum glucose levels are also a feature of asphyxiation (Randall 1979, Svendsen et al. 1986), and the low amount of liver glycogen histologically detected in this group may be due to either the glycogenolytic release of glucose in response to asphyxiation, or to poor storage ability, or to both.

However, other differences were also found between this group and the unaffected group which are not as easy to interpret (Table 3). These observations included the lower amount of lipids detected in the liver cells; more irregularities in the histological picture of the liver lobes; more developmental disturbances in the kidneys; and some differences in the appearance of the thyroid. Taken together with the low body weight of many intrapartum dead pigs, these may indicate that there has been a disturbance in the fetal growth pattern, supporting the suggestion by Svendsen (1982) that the hypoxia syndrome in some cases may be "superimposed upon a prior disease or abnormality of the affected individuals, rendering them incapable of making a successful transition to extrauterine life".

Other differences observed between the stillborn i.p. group and the unaffected group may be related to some type of prolonged intrauterine stress. The adrenals of the stillborn i.p. group are significantly heavier than those of unaffected littermates (Svendsen 1982), and it was observed that less lipids were present in this organ (Table 3). These observations may indicate that there has been an increased corticosteroid production and release over an extended period of time, which also may account for the observation of fewer Malpighian follicles in the splenic white pulp, the greater amount of cortical atrophy in the thymus of this group, and the low birth weight. On the other hand, at birth, many intrapartum dead pigs have significantly lower cortisol levels than the unaffected littermates (Svendsen et al. 1986). This would indicate that their capacity for mounting an adequate endocrine response is exhausted by the time birth is reached, and they are incapable of playing the part in the birth process dictated by high cortisol levels. A practical observation in support of this hypothesis is that stillborn i.p. pigs take a significantly longer time to be born than unaffected littermates (Svendsen et al. 1984). 
Table 3. Histomorphological observations of organs according to mortality group; comparison with those of the unaffected group.

\begin{tabular}{|c|c|c|c|c|c|c|}
\hline \multirow[t]{2}{*}{ Organ characteristics } & \multicolumn{6}{|c|}{$\%$ pigs in mortality group with a high degree of specific organ characteristics 1} \\
\hline & Unaffected & Stillborn & Weak & Splayleg & Splayweak & Trauma \\
\hline \multicolumn{7}{|l|}{ Lungs } \\
\hline Bronchiolar contraction & 22 & 40 & $16^{*}$ & 10 & $11^{* * *}$ & $8^{+}$ \\
\hline Atelectasis & 52 & $77^{* * *}$ & 53 & $27^{+}$ & $26^{*}$ & 43 \\
\hline Hyperemia & 7 & $62^{* * *}$ & $21^{* * *}$ & 15 & $29^{* * *}$ & $19^{+}$ \\
\hline Edema & 14 & $64^{* * *}$ & $27^{* * *}$ & $0^{+}$ & 12 & $21^{*}$ \\
\hline \multicolumn{7}{|l|}{ Liver } \\
\hline Glycogen in cells & 43 & $21^{* * *}$ & 33 & 34 & $13^{* *}$ & 35 \\
\hline Lipids in cells & 61 & $24 * * *$ & $34^{* *}$ & $37^{*}$ & $8^{* * *}$ & 54 \\
\hline Hyperemia & 22 & $62^{* * *}$ & $37^{* *}$ & 14 & $44^{*}$ & $39^{*}$ \\
\hline \multicolumn{7}{|l|}{$\begin{array}{l}\text { Dilatation of sinusoids with } \\
\text { irregular arrangements of }\end{array}$} \\
\hline Connective tissue in portal & 17 & $5 L^{+4}$ & $28^{+}$ & 4 & $28^{+}$ & $20^{\circ}$ \\
\hline spaces & 11 & 12 & 18 & $40^{+}$ & $32^{*}$ & 0 \\
\hline \multicolumn{7}{|l|}{ Kidneys } \\
\hline $\begin{array}{l}\text { Hyperemia and bleeding in } \\
\text { the cortex }\end{array}$ & 22 & $67^{* * *}$ & 7 & 15 & 8 & 31 \\
\hline Medullary hyperemia & 18 & $75^{* * *}$ & $39^{* *}$ & 9 & $38^{*}$ & 30 \\
\hline $\begin{array}{l}\text { Degenerative changes in } \\
\text { convoluted tubules }\end{array}$ & 4 & $36^{* *}$ & $15^{+}$ & 27 & 20 & $25^{*}$ \\
\hline \multicolumn{7}{|l|}{ Spleen } \\
\hline No. Malpighian corpuscles & 4.71 & $1.50^{* * *}$ & 3.69 & 4.44 & 4.41 & $2.50^{* * *}$ \\
\hline Extramedullary hematopoiesis & 48 & 44 & 50 & 35 & $24^{*}$ & 59 \\
\hline \multicolumn{7}{|l|}{ Thymus } \\
\hline Atrophy of the cortex & 28 & $50^{* *}$ & 30 & $15^{+}$ & 36 & $25^{*}$ \\
\hline Interlobulary edema & 12 & 15 & $18^{* *}$ & 11 & $28^{* *}$ & 34 \\
\hline \multicolumn{7}{|l|}{ Pancreas } \\
\hline Islets of Langerhans & 27 & 34 & $56^{*}$ & 28 & $48^{+}$ & 35 \\
\hline $\begin{array}{l}\text { Clusters of pycnotic nuclei } \\
\text { in exocrine gland }\end{array}$ & 46 & 37 & $26^{* *}$ & 44 & $29^{+}$ & 62 \\
\hline \multicolumn{7}{|l|}{ Thyroid } \\
\hline Vacuoles in follical colloids & 68 & $31^{* *}$ & 75 & 75 & 75 & $40^{*}$ \\
\hline $\begin{array}{l}\text { Interfollicular clustering } \\
\text { of epithelial cells }\end{array}$ & 55 & 44 & $30^{*}$ & $30 * *$ & 44 & $33^{*}$ \\
\hline Colloid free follicles & 25 & $73^{* * *}$ & 21 & 16 & 29 & $34^{*}$ \\
\hline \multicolumn{7}{|l|}{ Adrenals } \\
\hline Lipids in cortex & 40 & $20^{+}$ & 24 & 35 & $20^{+}$ & 40 \\
\hline
\end{tabular}

1 A high degree of the specific organ characteristic $=3$ or 4 , according to a scale of $1-4$, where $1=$ none or insignificant; mean scores of each organ characteristic adjusted for the linear effects of body weight, age, gestation length and litter size, and the percentage adjusted according to the changes in the respective mean scores. Significance levels obtained by covariance analysis, ${ }^{* * *}=\mathrm{P}<0.001,{ }^{* *}=\mathrm{P}<0.01$, ${ }^{*}=\mathrm{P}<0.05,^{+}=\mathrm{P}<0.10$. Data obtained by a study of 183 pigs. 
Weak and splayweak groups

These groups had, in comparison to the unaffected group, histomorphological pictures showing many similarities to those of the stillborn i.p. (Table 3). There were more circulatory disturbances in the lungs, such as hyperaemia, with the lungs of the weak group also showing a greater amount of oedema; more hyperaemia in the liver; more medullary hyperaemia in the kidneys; and more interlobulary oedema in the thymus, than the unaffected group. The liver cells had fewer histologically detectable lipids, with those of the splayweak group also having less glycogen. Both groups showed more irregularities in the construction of the liver lobules and more anomalies in the development of the kidneys convoluted tubules although only those of the weak group approached statistical significance. The weak and the splayweak groups also showed a tendency to have less lipids in the adrenals.

All these observations may indicate that many weakborn and splayweak pigs have been exposed to periods of intrauterine hypoxia, and that there are some similarities in the circumstances leading to the appearance of stillborn i.p. weak and splayweak piglets. However, the origin of the other differences noted in the weak and splayweak groups, such as an increase in the number of islets of Langerhans in the endocrine pancreas and fewer atrophic acinar cells with pycnotic nuclei in the exocrine pancreas; less extramedullary haematopietic cells in the spleen of the splayweak group and less interfollicular tissue in the thyroid of the weak group, remain to be explained.

\section{Splayleg group}

The phenomenon of splayleg in piglets has been the subject of many investigations. In most cases, interest has been centered on studies of the muscles (Ward 1978a, b) but none of these studies have given an acceptable explanation for the appearance of splayleg in certain pigs.

Svendsen (1982) found that the splayleg group had a significantly higher brain ratio (cerebellum: whole brain organ weight ratio) than did the unaffected group. In addition, the weights of the thymus were significantly lighter. Several observations from this histomorphological investigation (Table 3 ), such as less atelectasis in the lungs; less histomorphologically detectable lipids and more connective tissue in the portal spaces of the liver; fewer cases of thymic cortex atrophy; than the unaffected group, also indicated that splayleg is not just a local phenomenon in the pig.

Tucek et al. (1985) suggested that splayleg is a type of glucocorticoid myopathy occurring due to stress during pregnancy and a hereditary susceptibility to stress-provoking factors or increased sensitivity to glucocorticoid hormones. However, the results of Svendsen (1982) and Coussement (Coussement et al. 1984, Ducatelle et al. 1984) disagreed with this hypothesis, and our present results indicated that the brain and the thymus should be target organs for further studies of this syndrome.

These results and those of the organ weight study (Svendsen 1982) showed that there is some relationship between the splayleg and splayweak groups. They were the only groups that had less atelectasis in the lungs and more connective tissue in the liver than the unaffected group. Only these two groups had significantly lower thymus weights than the unaffected group (Svendsen 1982); at least for the splayleg pigs, cortical atrophy did not appear to be the cause of the lower weights since it was present in only a few of these pigs (Table 3). However, these findings still remain to be interpreted. 
$N$-E. Björklund, J. Svendsen and L. S. Svendsen: Histomorphological studies of the perinatal pig: Comparison of five mortality groups with unaffected pigs.



Figure 1. Liver section from a stillborn intra partum pig showing dilated sinusoids with ruptured walls, bleedings, and irregular arrangement of the liver plates. Hematoxylin and eosin stain. Original magnification $250 \times$.

Figure 2. Thyroid of stillborn intra partum pig showing areas with many colloid free follicles. PAS stain. Original magnificatiom $250 \times$. 


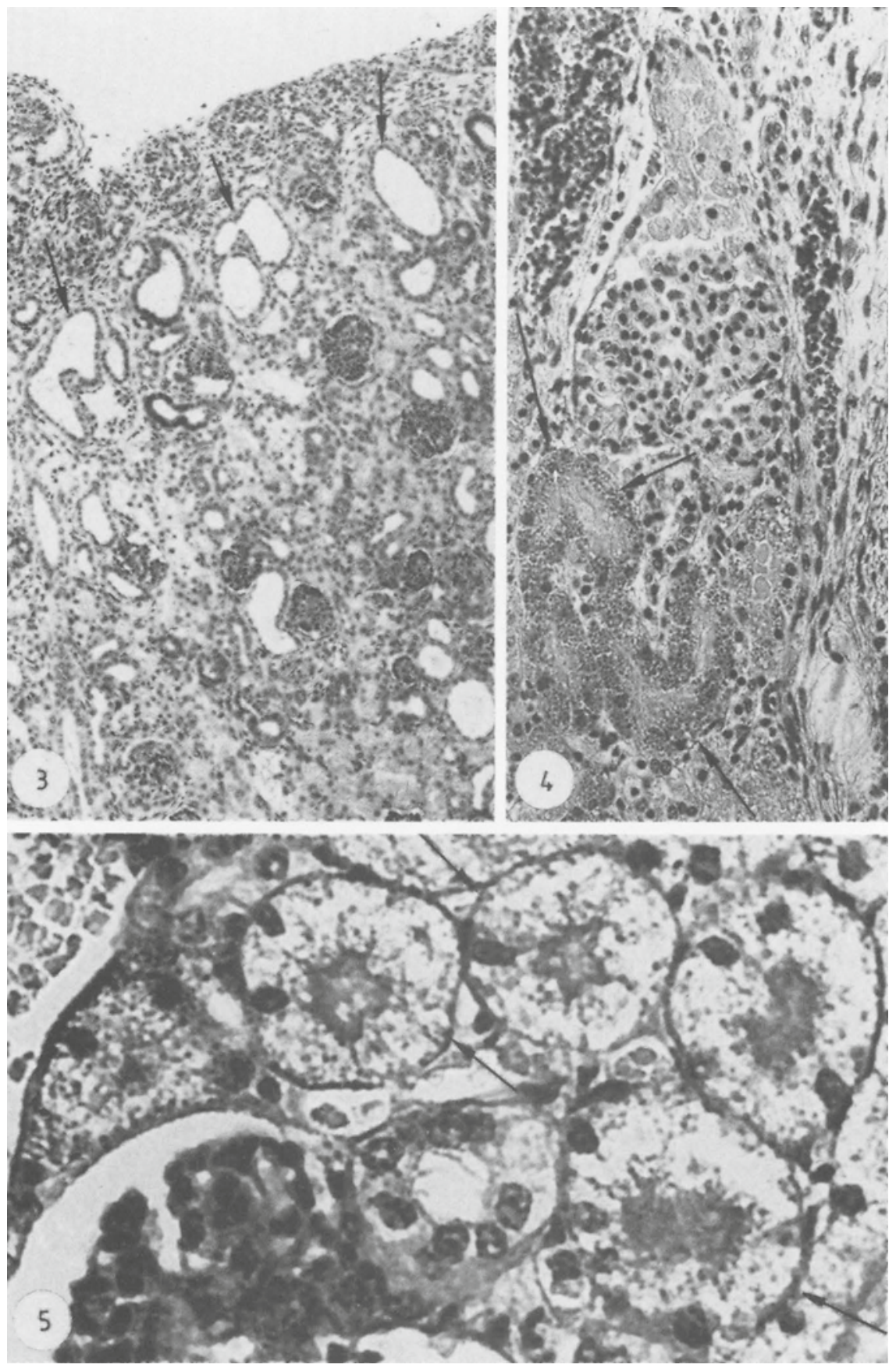

Figures 3, 4 and 5. Kidney of a stillborn intra partum pig, showing degenerative changes in the convoluted tubules. Cystic dilatations (arrow, Fig. 3), hyalin drop degeneration (arrow Fig. 4) and vacuolar degeneration (arrow, Fig. 5). Hematoxylin and eosin stain (Figs. 3, 4), PAS stain (Fig. 5). Original magnification $100 \times$ (Fig. 3), $250 \times$ (Fig. 4), $630 \times$ (Fig. 5). 


\section{Trauma group}

The trauma group in this investigation consisted of apparently normal vigorous pigs that died because the sow injured them in some manner. However, the histomorphological examination showed some differences between the organ characteristics of this group and the unaffected group. The presence of hyperaemia in the lungs and the liver may be explained as a consequence of a shock phenomenon due to the trauma. However, other differences were observed, such as a decrease in the amount of bronchiolar contractility, abnormalities in the appearance of the kidney tubular tissue, a decrease in the number of Malpighian follicles in the spleen and the amount of thyroid follicles with vacuolated collod. With consideration to the observations that the male trauma pigs have significantly heavier thyroids than the male unaffected pigs, and the females a lower brain ratio than the female unaffected pigs (Svendsen 1982), the suspicion arises that many of the pigs in this group are not as "normal" as the clinical appearance indicated.

\section{Other histomorphological observations among the mortality groups}

Table 3 only contains those observations that were made in both the unaffected groups and the mortality groups. However, some changes were seen among individual members of the mortality groups which should be mentioned. These changes were especially noted in the lungs. Sometimes, a PAS-positive (proteinaceous) oedema was observed in the alveoli, and occassionally hyaline membrane was seen. A purulent broncho-pneumonia was noted in one weak pig. The term "atelectasis", as used in the text, is a collective name for all the situations where the alveoli are compressed in some part of the lungs. A form commonly seen in this material was a total (as seen in some stillborn i.p. pigs) or remaining part of a fetal atelectasis (atelectasis neonatorum). In some cases, pulmonary collapse with increased cellular density, resembling a pulmonary abnormality recently described in newborn lambs (Richardson 1984), was observed. However, no histomorphological picture resembling that seen in the respiratory distress syndrome described in premature children, foals, lambs and in Barker's syndrome in pigs (Wrathall et al. 1977), was found in this material.

\section{Conclusions}

This histomorphological investigation of piglets was carried out by a single person who evaluated the individual cases without previous knowledge of the mortality group. The study is far from complete, and only gives a rather rough outline of some differences observed between unaffected piglets and piglets belonging to some common mortality groups. Some of the observations in the lungs, liver, kidneys, lymph-forming organs and endocrine glands ought to be further examined to provide a better understanding of the nature of the various observations, and to give a better appreciation of the relationship between them.

However, this study and the organ weight analysis made on the same material (Svendsen 1982) provides additional information on the problem of perinatal mortality in pigs. It is important to note that multivariate statistical analysis enabled comparison of the different groups.

Finally, it should be emphasized that the mortality groups are not homogenous entities, but represent a collection of animals having certain characteristics, as established by clinical observation or by post mortem, in common. As a result, certain of these groups,especially those of the stillborn intra 
partum pigs and the traumatized pigs, will in all likehood contain normal "unaffected" pigs which died due to "misadventure" being in the wrong place at the wrong time. The method of analysis used in our studies, relies upon the comparison of a mean for each group. For these groups, it would perhaps be of benefit for the understanding of the etiology of the deaths to examine the pattern of characteristics for the individual pigs, and then compare the groups. But that apart from the results and discussion the following conclusions were made:

1. For the stillborn intra partum pigs, some of the observations may have been due to hypoxia. Other differences indicated that there has been a certain amount of disturbance in the fetal growth pattern. Some findings have been discussed as an expression of a stress syndrome.

2. The observations for the weak and the splayleg pigs had much in common with those of the stillborn intra partum pigs. 3. The splayleg pigs had some differences which indicated that the splayleg pigs have more problems than that of poor posture.

4. There is a relationship between the splayleg and the splayweak groups, since certain of the differences from the unaffected group were only found in these two groups.

5. The trauma group, which consisted of apparently normal, vigorous pigs that died because the sow injured them in some manner, had differences in the organ characteristics which could only partially be explained as a result of shock. The nature of some of these differences was such that it was suspected that many of the pigs in this group were not as normal as their clinical appearance indicated.

\section{Acknowledgements}

This work was supported by grant Nos. P 111 and P 139 from the Swedish University of Agricultural
Sciences (J. Svendsen) and by grant No. 600001-5 from the National Veterinary Institute (N-E. Björklund).

\section{References}

Bengtsson $A-C$, Svendsen $J$, Persson $G$ : Jämförande undersökning av dräktiga suggor i 4 olika inhysningssystem: Beteendestudier och renhetsstudier. (Comparison of four types of housing for sows in gestation: Behaviour studies and hygiene studies). Report 36. Dept. Farm Buildings, Swedish Univ. Agric. Sci. Lund 1983.

Bille $N$, Nielsen $N C$, Larsen JL, Svendsen J: Preweaning mortality in pigs. II. The perinatal period. Nord. Vet.-Med. 1974, 26, 294-313.

Björklund $N-E$, Svendsen J, Svendsen LS: Histomorphological studies of the perinatal pig: The unaffected pig. Acta vet. scand. 1987, 28, 93-104.

Coussement $W$, Ducatelle $R$, Hoorens J: Splayleg in piglets. Histology and histochemistry. Proceedings, 8th Int. Pig. Vet. Soc. Congr., Ghent 1984, p. 282.

DeRoth L, Downie HG: Evaluation of viability of neonatal swine. Canad. vet. J. 1976, 17, 275-279.

Dixon WJ, Brown MB: (editors). Biomedical Computer Programs, P-series,UCLA Press, Los Angeles, revised 1983.

Ducatelle R, Coussement W, Hoorens J: Splayleg in pigs in Belgium: Ultrastructural cytochemistry of muscle. Proceedings, 8th Int. Pig Vet. Soc. Cong., Ghent 1984, p. 260.

Glastonbury JRW: Preweaning mortality in the pig. Pathological findings in piglets dying before and during parturition. Austr. vet. J. 1977, 53, 282-286.

Jeppsson M, Svendsen J, Andreasson B: Beteendestudier på lösgående och fixerade sinsuggor under samma skötsel-, utfodrings- och stallförhållanden. (Behaviour studies on loose and confined dry sows maintained under the same husbandry, feeding and stable condi tions). Report 10. Swedish Univ. Agric. Sci., Dept. Farm Buildings, Lund 1980. 
Nielsen $N C$, Bille $N$, Svendsen J, Riising $H-J$ : Sygdomsbekæmpelse i sobesætninger. (Disease control in sow herds). Inst. Internal Medicine, Royal Vet. Agric. Univ., Copenhagen 1976.

Randall GCB: The relationship between arterial blood $\mathrm{pH}$ and $\mathrm{pCO}_{2}$ to the viability of the newborn piglet. Canad. J. comp. Med. 1971, 35, 141-146.

Randall GCB: Perinatal mortality. Some problems of adaption at birth. Adv. Vet. Sci. Comp. Med. 1978, 22, 53-81.

Randall GCB: Studies on the effect of acute asphyxia on the fetal pig in utero. Biol. Neonate 1979, 36, 63-69.

Randall GCB, Penny RHC: Stillbirths in pigs: The possible role of anoxia. Vet. Rec. 1967, 81, 359-361.

Randall GCB, Penny RHC: Stillbirths in pigs: Observations on blood lactic acid levels. Vet. Rec. 1968, 83, 57.

Richardson C: A pulmonary abnormality of newborn lambs. J. comp. Pathol. 1984, 94, 559567.

Smith WJ: Piglet mortality. The predisposing factors and the possible control of the more important of these. Proceedings 2nd Int. Pig Vet. Soc. Congr., Hannover 1972.

Svendsen J, Bengtsson A-Ch: Produktionssystem för smågrisuppoödning: Åtgärder för att reducera antalet klämda och trampade grisar. (Production systems for farrowing piglets: Methods for reducing the number of piglets traumatized by the sow). Research Leaders' Meeting, Part 3. Swedish Univ. Agric. Sci. Konsulentavd. rapporter, Allmänt 39, pp. 5:1-5:12, Uppsala 1982a.

Svendsen J, Bengtsson A-Ch: Perinatal mortality in pigs: Herd investigations of pigs with splayleg. Proceedings, 7th Int. Pig Vet. Soc. Congr. Mexico City 1982b, p. 164.

Svendsen J, Bengtsson A-Ch: Perinatal mortality in pigs: Factors contributory to the occurrence of intra partum dead pigs. Proceedings 8th Int. Pig Vet. Soc. Cong. Ghent 1984, p. 369.

Svendsen J. Svendsen LS, Bengtsson A-Ch: Re ducing perinatal mortality. In: Diseases of
Swine, 6th ed., Iowa State University Press, Ames, Iowa 1986, Ch. 71, pp.813-825.

Svendsen $J$, Weström BR, Svendsen LS, Bengtsson $A-C h$, Olsson BG, Karlsson BW: Some blood serum characteristics of newborn, unaffected pigs and of pigs dying within the perinatal period: Stillborn intra partum pigs, weakborn pigs, underweight pigs, and traumatized pigs. Swine in Biomedical Research, 1986, in press.

Svendsen LS: Organ weights of the newborn pig. Characterization and comparison of the organ weights of pigs dying within 48 hours of birth with those of unaffected, growing pigs: Stillborn intra partum pigs, weak pigs, splayleg pigs, splayleg and weak (splayweak) pigs and traumatized pigs. Acta vet. scand. 1982, suppl. 78.

Thurley DC, Gilbert FR, Done JT: Congenital splayleg og piglets: Myofibrillar hypoplasia. Vet. Rec. 1967, 80, 302-304.

Tucek ST, Svoboda J, Ricny A, Bass T, Soukup $T$, Vitek $V$ : The concentration of choline and the activities of chloline esterases, creatine kinase and lactate dehydrogenase in the blood plasma of piglets with the syndrome of splayleg (congenital myofibrillar hypoplasia). Z Zbl. Vet. Med. A. 1985, 32, 1-10.

Ward $P W$ : The splayleg syndrome in newborn pigs: A review. Part I. Vet. Bull. 1978a, 4, 279-295.

Ward $P W$ : The splayleg syndrome in newborn pigs: A review. Part II. Vet. Bull. 1978b, 5, 381-399.

Wrathall AE, Bailey J, Wells DE, Herbert $C N$ : Studies on the Barker (neonatal respiratory distress) syndrome in the pig. Cornell Vet. 1977, 67, 543-598. 


\section{Sammanfattning}

Histomorfologiska studier av grisar i perinatala perioden.

Resultaten av histologiska undersökning av organ härrörande från 0-60 timmar gamla kliniskt och morfologiskt identifierade mortalitetsgrupper, jämfördes med resultat av motsvarande studie av normala grisar i samma ålder och från samma besättning. Olika iakttagelser graderades blint i en skala $1-4$ där 1 angav ingen eller obetydlig förekomst och 4 höggraddig förekomst av respektive observation. Jämförelserna gjordes med hjälp av statistiska program erhållna från BMPD - Biomedical Computer Program.

Konstaterade differenser mellan normala djur och de olika mortalitetsgrupperna presenteras i Tabell 3. Ett försök till utvärdering av differenserna har gjorts.

\section{(Received November 7, 1986).}

Reprints may be requested from: J. Svendsen, Dept. of Farm Buildings, P. O. Box 624, S-220 06 Lund, Sweden. 